\title{
Changes Occurring in Immune Responsiveness of Single- and Twin- Bearing Comisana Ewes During the Transition Period
}

\author{
M. Caroprese, ${ }^{*}$ M. Albenzio, ${ }^{*}$ G. Annicchiarico, $†$ and A. Sevi ${ }^{\star 1}$ \\ *Dipartimento PRIME, Università di Foggia, Via Napoli 25, 71100 Foggia, Italy \\ †Istituto Sperimentale per la Zootecnia, via Napoli, 71020 Segezia-Foggia, Italy
}

\begin{abstract}
Changes induced by twin and single lambing in the immune response of 16 periparturient Comisana ewes were studied. Cell-mediated immune responses were evaluated by means of skin tests performed from $3 \mathrm{wk}$ before and up to d 35 after parturition. At d 21 and 7 before lambing, the sheep received an intramuscular injection of the antigen keyhole limpet hemocyanin (KLH), to which the animals had not been previously exposed, to determine their humoral immune response. Starting 3 wk before lambing and up to d 35 postlambing, the ewes were sampled to determine the plasma concentrations of anti-KLH antibody (IgG), IL-6, and IL-1 $\beta$. From parturition through d 35 postpartum, individual milk samples were collected for determination of anti-KLH IgG titers and IL- 6 and IL- $1 \beta$ concentrations by means of a capture ELISA. The number of lambs born affected IL-6 concentrations in ewe plasma; IL-6 secretion always was higher in ewes birthing twins than in single-lambing ewes. Apart from the number of lambs born, the concentrations of plasma IL-6 in ewes were higher at lambing than at d 21 antepartum and at d 35 postpartum. An interaction of number of lambs born $\times$ time of sampling was observed for plasma antibody titers to KLH. The IgG concentrations were significantly higher in single-bearing ewes than in twinbearing ewes before parturition and were very similar across groups after parturition. A time effect was found for the cell-mediated immune response and for antiKLH IgG concentrations in milk, such that at parturition, cellular responses were lowest, and the anti-KLH IgG concentration was highest. A significant correlation was found for IgG titers to KLH in plasma and milk. Results indicate that IL- 6 concentrations in blood can be considered a reliable indicator of stress connected to lambing and that the mammary gland is a microenvironment unrelated to blood stream with respect to interleukins expression. In contrast, a relationship was
\end{abstract}

Received July 27, 2005.

Accepted October 4, 2005.

${ }^{1}$ Corresponding author: a.sevi@unifg.it found for the IgG secretions in milk and blood, which suggests that the assessment of humoral immune status may be combined with milking routine in dairy animals.

Key words: ewe, immune response, interleukin, transition period

\section{INTRODUCTION}

Several investigations have demonstrated that metabolic and physical stressors connected to parturition are responsible for alterations in the immune status of dairy cows during the transition period, which begins 3 wk before calving and continues for a few weeks after (Mallard et al., 1998). A full characterization of all of the factors involved in alteration of host defense mechanisms occurring at this time is needed to plan prophylactic measures aimed at preventing disease in periparturient animals and sustaining health of offspring. Moreover, in lactating animals, the impairment of immune functions around parturition is associated with a heightened susceptibility to mastitis (Kehrli et al., 1989). Hence, traits of systemic and mammary gland immunity have to be measured during the peripartum period.

Little is known about the changes occurring in ewe immune status during the transition period. Dairy sheep farmers aim at enhancing ewe conception rate and prolificacy through management practices and nutritional and breeding strategies to increase the amount of lamb meat for the market. In addition, prolificacy has a beneficial effect on ewe milk yield (Hamann et al., 2004). However, in prolific ewes, the most pronounced activation of homeorhetic mechanisms in support of multiple pregnancy and lactogenesis, which is related to a more intense hormonal secretion by the placenta, the anterior pituitary, and multiple corpora lutea (Manalu and Sumaryadi, 1998), may interfere with the maintenance of physiological equilibrium and the integrity of immunological functions. Sevi et al. (1998) found a reduced content and altered spectrum of amino acids in the milk of twin-lambing ewes and hypothesized that their extensive oxidation was necessary for energy supply, which could at least partly impair the synthesis of 
both cells and molecules responsible for immune responses.

Immune suppression around calving has been measured in terms of lymphocyte proliferation in vitro, antibody secretion, and cytokine release (Kehrli et al., 1989; Mallard et al., 1997). Both cell-mediated and humoral responses are activated and regulated by proinflammatory cytokines, such as IL- 6 and IL- $1 \beta$. Interleukin6 stimulates B cells, cytotoxic T cells, and hepatocytes (McWaters et al., 2000); IL-1 $\beta$ promotes leukocyte accumulation in inflamed sites by inducing adhesion receptors on vascular endothelium (Stylianou and Saklatvala, 1998). Both IL-6 and IL-1 $\beta$ are regarded as the principal mediators of the secretion of other proinflammatory cytokines and of the acute phase protein synthesis by the liver (Rothel et al., 1997; Yoshiota et al., 2002). Winter and Colditz (2002) found elevated concentrations of IL- $1 \beta$ and IL-6 in ewe milk after experimental mammary infection with Staphylococcus epidermidis.

The present study was undertaken 1) to monitor the cell-mediated and humoral immune response in vivo and the IL- 6 and IL-1 $\beta$ concentrations in blood and milk of single- and twin-bearing dairy ewes during the transition period, and 2) to assess the existence of a relationship between blood and milk immune traits.

\section{MATERIALS AND METHODS}

\section{Animals and Experimental Treatments}

Twenty periparturient Comisana ewes were randomly selected from an intensively managed flock at the Segezia research station of the Italian Istituto Sperimentale per la Zootecnia of Segezia, Foggia (latitude = $41^{\circ} 27^{\prime} 6^{\prime \prime}$ and longitude $\left.=15^{\circ} 33^{\prime} 5^{\prime \prime}\right)$. The ewes involved in the experiment, aging from 4 to $6 \mathrm{yr}$, were monitored for immune traits, as described subsequently, during the 3 wk before lambing (early February). At parturition, 16 ewes were selected from the starting group of 20 and assigned to 2 groups of 8 single- and 8 twinlambing ewes, which were balanced for age, BW, and BCS. Throughout the trial, single-and twin-bearing ewes were separately grouped in straw-bedded pens. The ewes in the single and twin lambing groups were monitored from parturition up to 5 wk later.

Ewes were healthy, and their condition was judged as good at the commencement of the trial. Before starting and throughout the trial, the ewes were carefully examined by veterinarians to exclude the presence of signs of clinical mastitis (pain, gland swelling, fever) and a small quantity of milk was checked visually for signs of mastitis. No cases of mastitis were detected during the study period.
The cell-mediated immune status of sheep was evaluated by means of skin tests that were performed on all animals at $d-21,-7,0,7,14$, and 35 from parturition. During each test, $0.7 \mathrm{mg}$ of phytohemagglutinin dissolved in $1 \mathrm{~mL}$ of sterile saline solution was injected intradermally into the center of a 2 -cm wide circle marked on shaved skin in the upper side of each shoulder. The average increase in skinfold thickness $(24 \mathrm{~h}$ postinjection thickness - preinjection thickness) of each animal was calculated using the 2 measurements gathered with a caliper.

To determine the ewe humoral response peripartum, 21 and $7 \mathrm{~d}$ before lambing, the animals received an i.m. injection of the antigen keyhole limpet hemocyanin (KLH; Sigma-Aldrich, Milan, Italy) to which the animals had not been previously exposed. Prior to injection, the antigen (5 mg per ewe) was dissolved in $1 \mathrm{~mL}$ of sterile saline solution and in $1 \mathrm{~mL}$ of incomplete Freund's adjuvant (Sigma-Aldrich). A third i.m. injection, without Freund's adjuvant, was administrated at parturition.

\section{Sampling and Analysis of Blood}

Peripheral blood samples were collected from the jugular vein in heparinized vacuum tubes (Becton Dickinson, Plymouth, UK) immediately before the first KLH injection (-21 d) and then at $-7,0,3,7,14$, and $35 \mathrm{~d}$ of the peripartum period. Blood samples were centrifuged $(1,500 \times g$ for $20 \mathrm{~min})$ to obtain plasma and then stored frozen at $-20^{\circ} \mathrm{C}$ until time of assay. Plasma samples were used to perform ELISA to evaluate the anti-KLH IgG titers, IL- $1 \beta$ and IL- 6 concentrations.

\section{Sampling and Analysis of Milk}

Milk samples were individually collected at parturition and then at $3,7,14$, and $35 \mathrm{~d}$ after lambing. The ewes were separated from their lambs the evening before each sampling day, and milk samples were taken from the whole milk of the machine milking in the morning. Milk was centrifuged $(2,500 \times g$ for $20 \mathrm{~min}$ at $4^{\circ} \mathrm{C}$ ) to separate the cell-free aqueous whey fractions to evaluate the antibody titer to KLH and the concentrations of IL- $1 \beta$ and IL-6.

\section{ELISA for Anti-KLH IgG Detection in Plasma and Milk Whey}

The concentrations of IgG anti-KLH in plasma and milk whey were determined by a sandwich ELISA performed on microtiter plates. Wells were coated with the antigen $(0.5 \mathrm{mg}$ of $\mathrm{KLH} / \mathrm{mL}$ of PBS) and incubated overnight at $4^{\circ} \mathrm{C}$. Subsequently, plates were washed 
Table 1. Least squares means \pm SEM of IL- $1 \beta$ optical density by capture ELISA measured in blood and milk of single-lambing (SL) and twin-lambing (TL) ewes

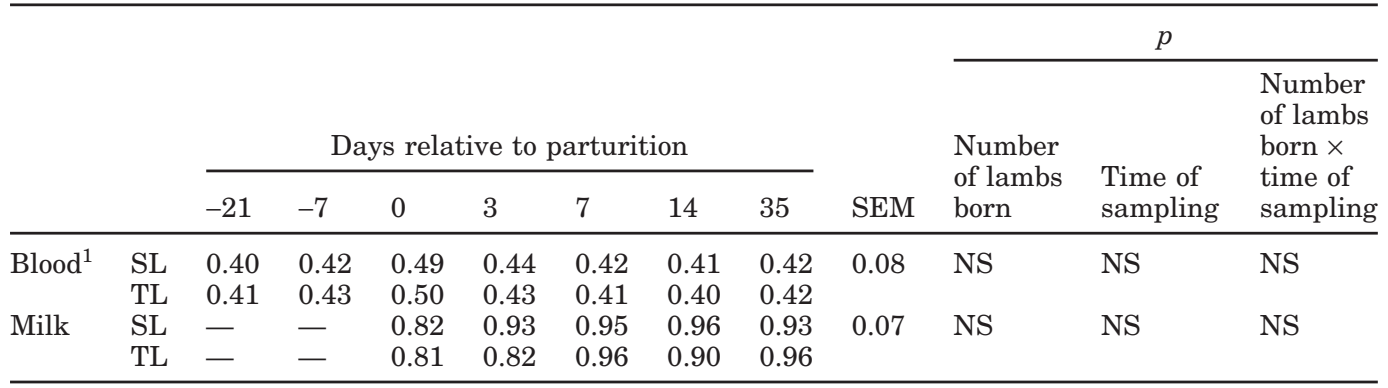

${ }^{1}$ Diluted 1:4 in PBS.

with PBS (pH 7.2) and 0.05\% Tween 20 and incubated with $10 \%$ reconstituted bovine skim milk at $37^{\circ} \mathrm{C}$ for $1 \mathrm{~h}$ to block nonspecific binding. After washing, the plasma (1:200 in PBS; $100 \mu \mathrm{L}$ per well) or milk whey (1:8 dilution in PBS; $100 \mu \mathrm{L}$ per well) was added and incubated at $37^{\circ} \mathrm{C}$ for $1 \mathrm{~h}$. Buffer alone provided negative control wells. The extent of antibody binding was detected using a donkey antisheep IgG conjugated to peroxidase (Sigma Aldrich). Plates were incubated for $1 \mathrm{~h}$ at $37^{\circ} \mathrm{C}$ after washing and adding $100 \mu \mathrm{L}$ of conjugated antibody per well (1:20,000 in PBS). Buffer alone provided blank wells. After a further washing, $100 \mu \mathrm{L}$ of substrate consisting of tetra methyl benzidine free base tablets (Sigma Aldrich) and dimethyl sulfoxide (Sigma Aldrich) dissolved in $0.05 M$ phosphate-citrate buffer (pH 5.0) and $\mathrm{H}_{2} \mathrm{O}_{2}$ was added to each well and incubated for $30 \mathrm{~min}$ at $37^{\circ} \mathrm{C}$. Finally, $2 M \mathrm{H}_{2} \mathrm{SO}_{4}$ was added to terminate reactions. Optical density was measured at a wavelength of $450 \mathrm{~nm}$ using Rosys Anthos 2020 ELISA reader (Diessechem, Milan, Italy). The intra- and interassay coefficients of variation were 3.2 and $7.8 \%$, respectively.

\section{Capture ELISA for IL-6 and IL-1 $\beta$ Detection in Plasma and Milk Whey}

The detection of IL-6 (Rothel et al., 1997) and IL-1 $\beta$ (McWaters et al., 2000) in plasma and milk whey was determined by capture ELISA performed on 96-well microtiter plates. Mouse monoclonal antibodies specific for IL-6 and IL-1 $\beta$ (Serotec Ltd., Oxford, UK) $(100 \mu \mathrm{L}$, $5 \mu \mathrm{g} / \mathrm{mL}$ ) dissolved in $50 \mathrm{mM}$ carbonate buffer ( $\mathrm{pH}$ 9.6) were used to coat wells and were incubated overnight at $4^{\circ} \mathrm{C}$. After washing with PBS (pH 7.2) and $0.05 \%$ Tween 20, plates were incubated with $10 \%$ reconstituted bovine skim milk at $37^{\circ} \mathrm{C}$ for $1 \mathrm{~h}$ to block nonspecific binding. Plates were then washed 4 times with PBS (pH 7.2) and $0.05 \%$ Tween 20 , and the plasma or milk whey $(100 \mu \mathrm{L}$ per well) was added and incubated at $37^{\circ} \mathrm{C}$ for $1 \mathrm{~h}$. Buffer alone provided negative control wells. Rabbit polyclonal antibodies anti-IL-6 and antiIL-1 $\beta$ (Serotec Ltd.) were used as detecting antibodies (1:200 diluted in PBS) to determine captured IL- 6 and IL- $1 \beta$ and incubated at $37^{\circ} \mathrm{C}$ for $1 \mathrm{~h}$. The presence of antibody bindings was detected using goat antirabbit IgG conjugated to horseradish peroxidase (Sigma Aldrich). The following steps were carried out as described previously for the anti-KLH IgG detection. The intraand interassay coefficients of variation were 5.3 and 8.6\% for IL-6 and 6.4 and $8.9 \%$ for IL- $1 \beta$.

The assays were optimized in our laboratory for concentrations of monoclonal coating antibody, plasma and milk whey, polyclonal detecting antibody, and secondary conjugate antibody.

All procedures were conducted according to the guidelines of the Council Directive 86/609/EEC of November 24, 1986 (European Communities, 1996) on the protection of animals used for experimental and other scientific purposes.

\section{Statistical Analyses}

Milk and blood variables were analyzed with an ANOVA procedure for repeated measures and were processed using the GLM procedure of SAS (1999); number of lambs born, time of sampling, and their interactions were sources of variation. Individual animal variation within number of lambs born was used as the error term. Where significant effects were found $(P<0.05)$, the Student's $t$-test was used to locate significant differences between means.

Linear simple correlations between milk and blood variables were investigated using PROC CORR of SAS (1999).

\section{RESULTS}

\section{Cell-Mediated and Humoral Immune Responses}

The skinfold thickness measured after the phytohemagglutinin injection was affected by time of sampling 


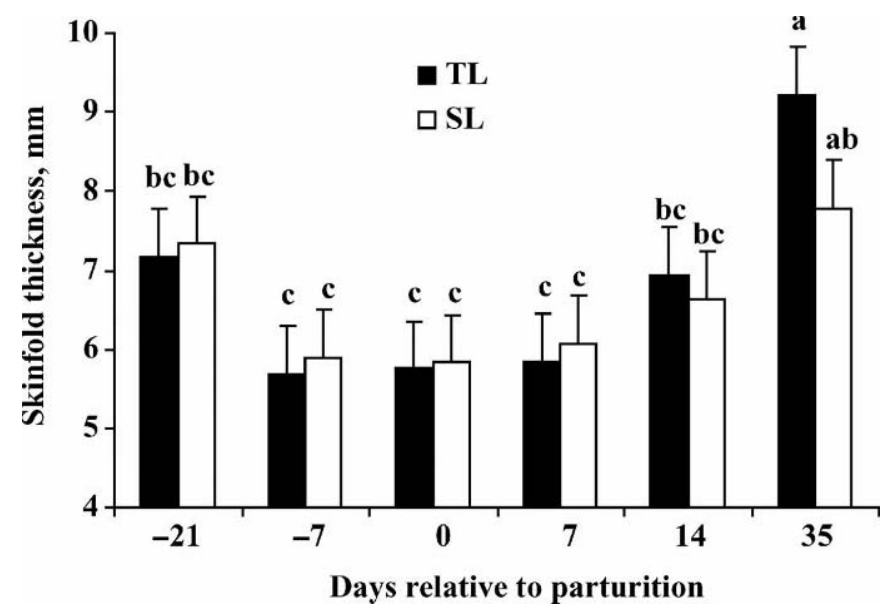

Figure 1. Skinfold thickness (LSM $\pm \mathrm{SE}$ ) after phytohemagglutinin injection in single lambing (SL) or twin lambing (TL) Comisana ewes at $d-21,-7,0,7,14$, and 35 from parturition. ${ }^{a-c}$ Values with different superscripts differ $(P<0.05)$.

$(P<0.001$; Figure 1); in fact, significantly lower average values were recorded at $-7,0$ and $7 \mathrm{~d}(P<0.001)$ than at $35 \mathrm{~d}$ postparturition. In twin-lambing ewes, a significant increase in the cell-mediated immune response $(P<0.01)$ was also recorded when passing from $\mathrm{d} 14$ to 35 postpartum (6.94 vs. $9.21 \mathrm{~mm}$, respectively).

An interaction of number of lambs born $\times$ time of sampling $(P<0.001)$ was observed for plasma antibody titers to KLH (Figure 2). Such effect can be ascribed to the detection of significantly higher antibody concentrations $(P<0.05)$ in single-lambing ewes than in twinlambing ewes before parturition and the failure to find any differences between groups in plasma IgG at lambing and thereafter.

Antibody titers to $\mathrm{KLH}$ in milk showed a significant effect of time of sampling $(P<0.001)$; the IgG concentrations were lower $35 \mathrm{~d}$ postpartum $(P<0.001)$ than on all previous sampling days. No differences were observed between groups for this trait.

From all of the linear correlations investigated, a significant relationship ( $\mathrm{r}=0.22, P<0.05)$ was found only for IgG titers to KLH in plasma and milk.

\section{IL-6 and IL-1 $\beta$ Detection in Plasma and Milk Whey}

Number of lambs born $(P<0.01)$ altered the IL-6 detected in ewe plasma (Figure 3). The IL-6 secretion was always higher in twin-bearing ewes than in singlebearing ewes. Apart from the number of lambs born, the concentrations of IL- 6 in ewe plasma were significantly higher at lambing than at $\mathrm{d} 21$ antepartum and $\mathrm{d} 35$ postpartum $(P<0.05)$. No differences were detected between single-lambing and twin-lambing ewes for IL6 concentrations in whey ( 0.45 and 0.50 , respectively).
The IL-1 $\beta$ concentration in blood and whey was similar across groups and had slight, but not significant, changes throughout the study period (Table 1).

\section{DISCUSSION}

Results from the present study indicate that marked changes occurred in the immune responses of singleand twin-bearing ewes during the transition period and that antibody titers and plasma IL- 6 secretion were the most sensitive indicators of the stressfulness related to the number of lambs born.

In fact, in the present experiment, a lower antibody secretion against specific antigens was found in twinbearing ewes than in single-bearing ewes in the weeks prior to parturition. Dairy cows have reduced antibody secretion of B cells during the periparturient period (Kehrli et al., 1989; Detilleux et al., 1995). The level of antibody secretion against antigens can give a measure of graded levels of both physical and psychogenic stresses in sheep (Sevi et al., 2002, 2003; Napolitano et al., 2003). Hence, based on previous findings and present results, it could be argued that the twin-lambing ewes suffered more markedly from physiological adjustments related to pregnancy and parturition than the single-lambing ewes and that antibody titer to KLH was a sensitive indicator of the increase in metabolic and physical stresses connected to multiple pregnancy. Nonnecke et al. (2003) speculated that the reduction in plasma IgG concentrations of dairy cows immediately before and after calving is affected by the mammary gland uptake of $\mathrm{IgG}_{1}$ isotype from the blood through selective $I_{g G_{1}}$ receptors of alveolar epithelial cells. In contrast, a previous experiment had demonstrated that specific antibody response in serum does not necessarily relate to IgG sequestration by the mammary gland (Mallard et al., 1997). In the present experiment, twinand single-lambing ewes exhibited quite comparable IgG titers in blood and milk after parturition; serum antibody concentrations remained substantially constant, and milk IgG values underwent a gradual decrease. In addition, a close relationship emerged between antibody titers in blood and milk, which lends support to the possibility of using the antigen-specific antibody extent in milk for assessing systemic humoral immune competence in dairy ewes, as suggested by recent unpublished studies of this research group on immunological indicators of sheep well being.

In Holstein heifers, Kehrli et al. (1989) found that peripheral blood lymphocyte response to mitogen declined from $2 \mathrm{wk}$ before calving until the week of calving and then increased again at wk 2 postcalving. Results from the present experiment confirm the existence of a reduced $\mathrm{T}$ lymphocyte sensitivity to mitogen stimula- 

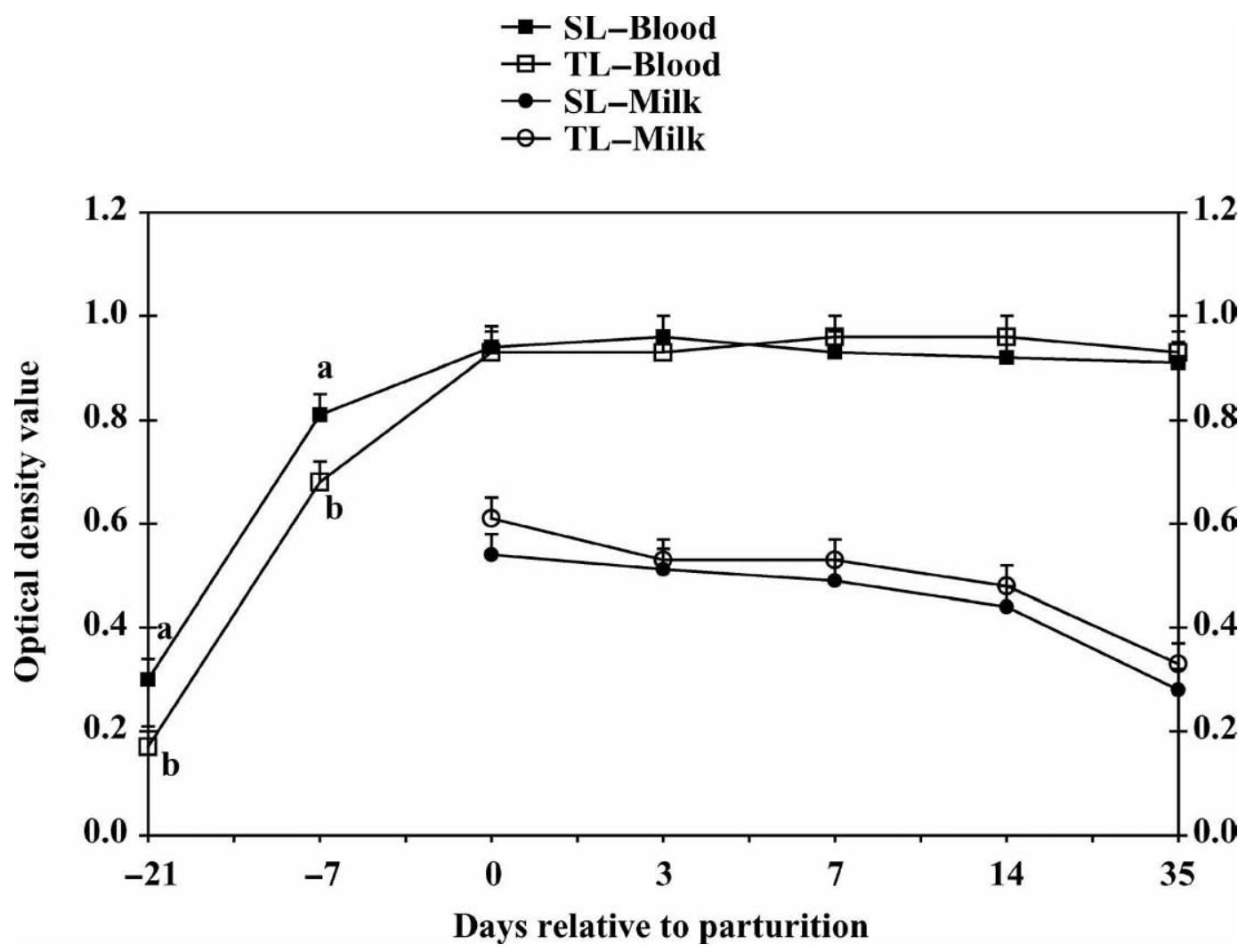

Figure 2. Antibody titers to keyhole limpet hemocyanin (KLH; LSM \pm SE) detected in blood samples and milk of single-lambing (SL) and twin-lambing (TL) Comisana ewes at d 21 and 7 before parturition and at d $0,3,7,14$, and 35 after parturition. ${ }^{\text {a,b}}$ Values with different superscripts differ between treatments within a sampling day $(P<0.05)$.

tion in vivo around parturition in dairy sheep, which could explain the unresponsiveness of this trait to the number of lambs born. High levels of circulating reproductive hormones and enhanced metabolic demands related to nutritional imbalance in late pregnancy, to parturition, and to the onset of lactation have been cited to explain the $\mathrm{T}$ cell hyporesponsiveness in periparturient cows (Kehrli et al., 1999; Nonnecke et al., 2003). In addition, soon after calving, the mammary gland can recruit $\mathrm{T}$ lymphocytes selectively from blood to milk via the expression of specific adhesion molecules, which regulate leukocyte trafficking (Harp et al., 2004). The rise in T lymphocyte responsiveness to phytohemagglutinin observed in twin-lambing ewes from 14 to $35 \mathrm{~d}$ postpartum may be interpreted as a more rapid recovery of the activity of $\mathrm{T}$ cells in ewes that experienced a multiple pregnancy. Some researchers (Sordillo et al., 1997; Kehrli and Harp, 2001) have hypothesized that a change occurs in the proportion of T lymphocyte subsets with Th2 phenotype expression (responsible of the humoral immune response) around parturition and a greater Th1 phenotype expression (responsible of the cell-mediated immune response) in midlactation.
Interleukin- 6 has a wide range of immunological functions, including stimulation of B cells and cytotoxic T cells (McWaters et al., 2000). Release and activity of IL-6 is strongly controlled and mainly occurs under inflammatory conditions, being partially responsible for the increase of certain acute phase proteins (Murata et al., 2004). The detection of higher IL-6 plasma concentrations in twin-lambing ewes than in single-lambing ewes, which was observed in the present experiment, suggests that plasma IL-6 secretion may be also stimulated by the physiological adjustments connected to multiple lambing.

The lack of differences in IL-6 concentrations in milk and the failure to find a significant correlation between plasma IL-6 concentration and anti-KLH IgG titers in blood or in milk are not easy to interpret. A tentative explanation may be the synergistic mediation of inflammatory interleukins and of hormones other than IL-6 on antibody secretion. The lack of consistent IL- 6 trends in blood and milk also could be attributed to the fact that this cytokine is likely to be quickly utilized by lymphocytes after having been secreted or inactivated by soluble receptors as described for human IL-6 (Lust 

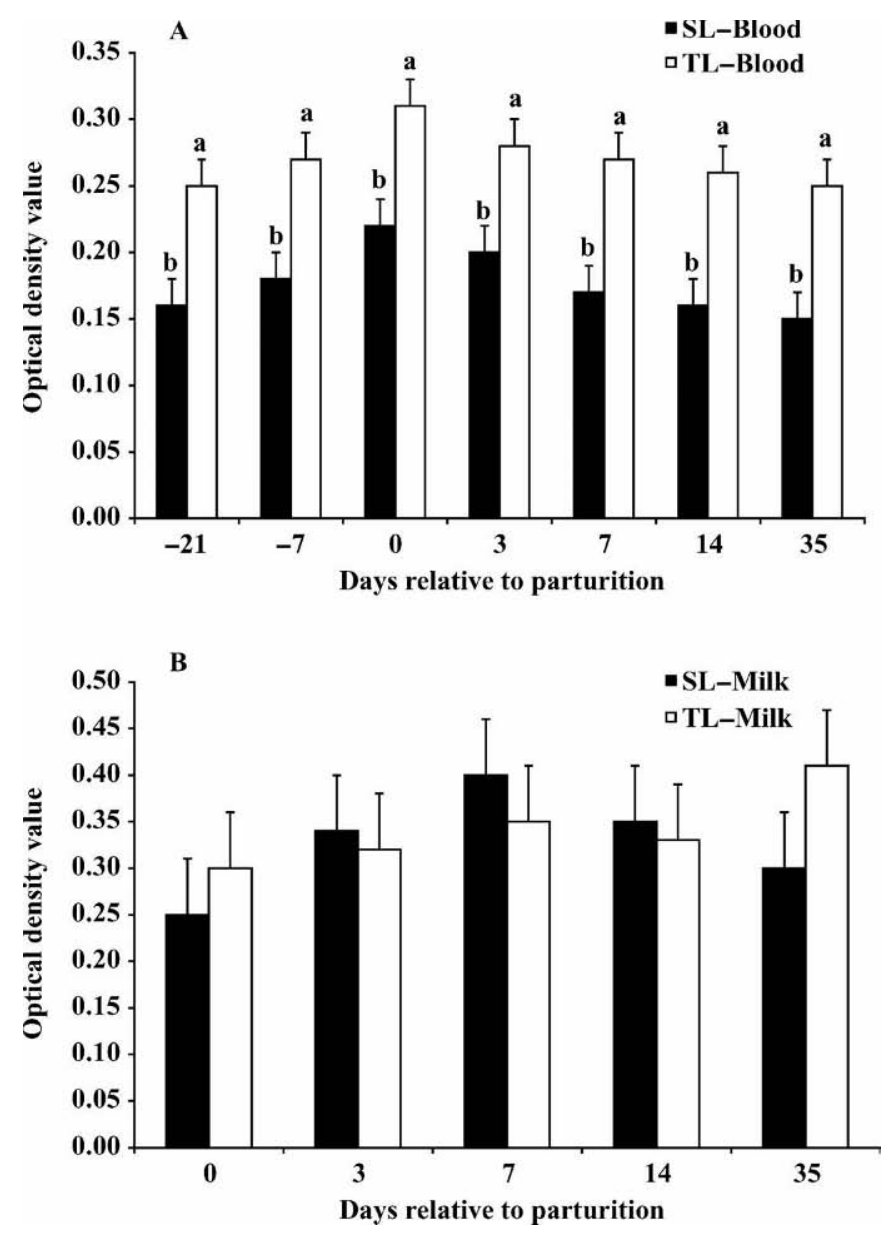

Figure 3. Interleukin- 6 optical density $(\mathrm{LSM} \pm \mathrm{SE})$ by capture ELISA detected in blood samples (A) and in milk samples (B) from single-lambing (SL) and twin-lambing (TL) Comisana ewes. Blood samples were collected at $\mathrm{d} 21$ and 7 before parturition and at $\mathrm{d} 0$, $3,7,14$, and 35 after parturition; milk samples were collected at d 0 , $3,7,14$, and 35 after parturition. ${ }^{a, b}$ Values with different superscripts differ $(P<0.05)$.

et al., 1992; McWaters et al., 2000). Hence, our results highlighted the inopportunity of considering IL-6 secretion in milk as an indicator of the physiological stress connected to parturition, differently from IL-6 concentration in plasma, which appeared to be suitable indicator for this purpose.

Interleukin-1 is known as an inflammatory cytokine involved in lymphocyte activation and is implicated in acute-phase response (Ohtsuka et al., 2001), host defense against bacterial and viral infections (Winter and Colditz, 2002), and stress responses (Kunz-Ebrecht et al., 2003). The production of detectable concentrations of IL- $1 \beta$ arises when there is a strong immune challenge (Duncan et al., 1991; Rothel et al., 1997). Moreover, other research groups failed to detect IL-1 in milk from cows immunized with Staphylococcus aureus $\alpha$-toxin
(Riollet et al., 2000). Although cytokine mRNA were expressed in cells from bovine milk, the concentrations of these cytokines (IL- $1 \beta$, IL- 6 , TNF- $\alpha$ and INF- $\gamma$ ), which are highly detectable in colostrum, were not detectable in the subsequent stages of lactation (Hagiwara et al., 2000). In our trial, detectable concentrations of IL- $1 \beta$ were found both in blood and milk, and a very similar IL-1 $\beta$ secretion was observed in single- and twin-lambing ewes. This result suggests that measurable IL- $1 \beta$ concentrations could be found in sheep milk during mature lactation, but this interleukin is synthesized or drawn from peripheral blood at such low concentrations that no differences are appreciable with respect to the number of lambs born. Other possible explanations for the failure to find differences in IL- $1 \beta$ concentrations between twin- and single-lambing ewes may be the highly localized secretion and synthesis of this interleukin, its short biological life, or even the presence of membrane-bound form in the mammary gland, as supposed by Persson Waller et al. (1997).

\section{CONCLUSIONS}

A full understanding of the mechanisms responsible for impaired immune function during the transition period requires the knowledge of those factors that control the number and activity of leukocytes in blood and in the mammary gland. The aim of the present study was the investigation of molecules stemming from leukocyte activity in sheep with respect to the number of lambs born. Results from our experiment demonstrated that the cell-mediated and humoral immune responses and plasma IL-6 concentrations underwent marked fluctuations in periparturient ewes and that plasma IgG titers and IL-6 concentrations in plasma, but not in milk, were the most sensitive indicators of relative stressfulness connected to the number of lambs born. Results also indicate that in sheep, mammary gland and blood are not overlapping compartments with respect to interleukin expression, whereas a relationship exists for immunoglobulin secretion in blood and milk, suggesting the possibility of monitoring sheep humoral immune response to specific antigen directly in milk.

The pursuit of prolificacy in dairy sheep flocks remains one of the main tools for increasing both the number of lambs for slaughter and the amount of milk to be processed into dairy products. However, our findings suggest that ewes with multiple births have impaired immune function and, therefore, possibly decreased resistance to pathogens.

\section{REFERENCES}

Detilleux, J. C., M. E. Kehrli, J. R. Stabel, A. E. Freeman, and D. H. Kelley. 1995. Study of immunological dysfunction in peripartur- 
ient Holstein cattle selected for high and average milk production. Vet. Immunol. Immunopathol. 44:251-267.

Duncan, L. M., L. S. Meegan, and E. R. Unanue. 1991. IL-1 gene expression in lymphoid tissues. J. Immunol. 146:565-571.

European Communities. 1986. Council Directive 86/609/EEC of 24 November 1986 on the approximation of laws, regulations and administrative provisions of the Member States regarding the protection of animals used for experimental and other scientific purposes. Pages 1-28 in Off. J. L 358. European Communities Publ. Office, Luxembourg.

Hagiwara, K., K. Satoshi, H. Yamanaka, R. Kirisawa, and H. Iwai. 2000. Detection of cytokines in bovine colostrum. Vet. Immunol. Immunopathol. 76:183-190.

Hamann, H., A. Horstick, A. Wessels, and O. Disti. 2004. Estimation of genetic parameters for test day milk production, somatic cell score and litter size at birth in East Friesian ewes. Livest. Prod. Sci. 87:153-160.

Harp, J. A., J. A. Stabel, B. A. Pesch, and J. P. Goff. 2004. Expression of adhesion molecules on milk and blood lymphocytes from periparturient dairy cattle with Johne's disease. Vet. Immunol. Immunopathol. 98:69-76.

Kehrli, M. E., J. L. Burton, B. J. Nonnecke, and E. K. Lee. 1999. Effects of stress on leukocyte trafficking and immune responses: Implications for vaccination. Adv. Vet. Med. 41:61-81.

Kehrli, M. E., and J. A. Harp. 2001. Immunity in the mammary gland. Vet. Clin. North Am. Food Anim. Pract. 17(Suppl. 3):495-516.

Kehrli, M. E., B. J. Nonnecke, and J. A. Roth. 1989. Alterations in bovine peripheral blood lymphocyte function during the peripartum period. Am. J. Vet. Res. 50:215-220.

Kunz-Ebrecht, S. R., V. Mohamed-Alì, P. J. Feldman, C. Kirschbaum, and A. Steptoe. 2003. Cortisol responses to mild psychological stress are inversely associated with proinflammatory cytokines. Brain Behav. Immun. 17:373-383.

Lust, J. A., K. A. Donovan, M. P. Kline, P. R. Greipp, R. A. Kyle, and N. J. Maihle. 1992. Isolation of an mRNA encoding a soluble form of the human interleukin-6 receptor. Cytokine 4:96-100.

Mallard, B. A., J. C. Dekkers, M. J. Ireland, K. E. Leslie, S. Sharif, C. Lacey Vankampen, L. Wagter, and B. N. Wilkie. 1998. Alteration in immune responsiveness during the peripartum period and its ramification on dairy cow and calf health. J. Dairy Sci. 81:585-595.

Mallard, B. A., L. C. Wagter, M. J. Ireland, and J. C. M. Dekkers. 1997. Effects of growth hormone, insulin-like growth factor-I, and cortisol on periparturient antibody response profiles of dairy cattle. Vet. Immunol. Immunopathol. 60:61-76.

Manalu, W., and M. Y. Sumaryadi. 1998. Maternal serum progesterone concentration during gestation and mammary gland growth and development at parturition in Javanese thin-tail ewes carrying a single or multiple fetuses. Small Rumin. Res. 27:131-136.
McWaters, P., L. Hurst, P. J. Chaplin, R. A. Collins, P. R. Wood, and J. P. Y. Scheerlinck. 2000. Characterisation of monoclonal antibodies to ovine interleukin- 6 and the development of a sensitive capture ELISA. Vet. Immunol. Immunopathol. 73:155-165.

Murata, H., N. Shimada, and M. Yoshioka. 2004. Current research on acute phase proteins in veterinary diagnosis: An overview. Vet. J. 168:28-40.

Nonnecke, B. J., K. Kimura, J. P. Goff, and M. E. Kehrli. 2003. Effects of the mammary gland on functional capacities of blood mononuclear leukocyte populations from periparturient cows. J. Dairy Sci. 86:2359-2368.

Ohtsuka, H., K. Kudo, K. Mori, F. Nagai, A. Hatsugaya, M. Tajima, K. Tamura, F. Hoshi, M. Koiwa, and S. Kawamura. 2001. Acute phase response in naturally occurring coliform mastitis. J. Vet. Med. Sci. 63:675-678.

Persson Waller, K., I. G. Colditz, P. Flapper, and H. F. Seow. 1997. Leukocyte and cytokine accumulation in the ovine teat and udder during endotoxin-induced inflammation. Vet. Res. Commun. $21: 101-115$

Riollet, C., P. Rainard, and B. Poutrel. 2000. Kinetics of cells and cytokines during immune-mediated inflammation in the mammary gland of cows systemically immunized with Staphylococcus aureus alpha-toxin. Inflamm. Res. 49(Suppl. 9):486-496.

Rothel, J. S., L. Hurst, H. F. Seow, M. Pépin, P. Berthon, L. A. Corner, and P. R. Wood. 1997. Analysis of ovine IL-1 $\beta$ production in vivo and in vitro by enzyme immunoassay and immunohistochemistry. Vet. Immunol. Immunopathol. 57:267-278.

SAS User's Guide. Statistics, Version 8.1 Edition. 1999. SAS Inst., Inc., Cary, NC.

Sevi, A., M. Albenzio, G. Annicchiarico, M. Caroprese, R. Marino, and L. Taibi. 2002. Effects of ventilation regimen on the welfare and performance of lactating ewes in summer. J. Anim. Sci. 80:2362-2372.

Sevi, A., L. Taibi, M. Albenzio, M. Caroprese, R. Marino, and A. Muscio. 2003. Ventilation effects on air quality and on the yield and quality of ewe milk in winter. J. Dairy Sci. 86:3881-3890.

Sevi, A., L. Taibi, A. Muscio, S. Dell'Aquila, and D. Casamassima. 1998. Quality of milk as affected by number of lambs and length of suckling. Ital. J. Food Sci. 3(Suppl. 10):229-241.

Sordillo, L. M., K. Shafer-Weaver, and D. DeRosa. 1997. Immunobiology of the mammary gland. J. Dairy Sci. 80:1851-1865.

Stylianou, E., and J. Saklatvala. 1998. Interleukin-1. Int. J. Biochem. Cell Biol. 30:1075-1079.

Winter, P., and I. J. Colditz. 2002. Immunological responses of the lactating ovine udder following experimental challenge with Staphylococcus epidermidis. Vet. Immunol. Immunopathol. 89:57-65.

Yoshiota, M., A. Watanabe, N. Shimada, H. Murata, Y. Yokomizo, and Y. Nakajima. 2002. Regulation of haptoglobin secretion by recombinant bovine cytokines in primary cultured bovine hepathocytes. Domest. Anim. Endocrinol. 23:425-433. 